\title{
A MOL 2030-as stratégiájának pénzügyi megvalósíthatósága és hatása a tulajdonosi értékre
}

\author{
Biró Zsófia \\ Pécsi Tudományegyetem
}

\begin{abstract}
A TANULMÁNY CÉLJA
Tanulmányomban a MOL 2030-as stratégiájának várható hatásait vizsgálom a vállalat tulajdonosi értékére nézve. Vajon a MOL Group képes lesz megfelelő vállalatértéket generálni, ha eljön a fosszilis korszak vége vagy ő sem menekülhet az eljövendő időszak elöl?
\end{abstract}

\begin{abstract}
ALKALMAZOTT MÓDSZERTAN
A vállalatértékeléshez szükséges kutatási módszertan kiválasztásánál figyelembe vettem a vonatkozó szakirodalmakat, nemzetközi standardokat. Ami minden esetben közös, hogy módszertanilag leginkább megfelelőnek a diszkontált cash flow módszert tekintik. Az egyes DCF modellek közül pedig az equity cash flow modellt választottam, hiszen a tulajdonosi értéket az ECF modell adja közvetlenül eredményként. A MOL 2030-as stratégiája négy, a tulajdonosi érték szempontjából lényeges beruházást említ: finomítók fejlesztését, mủanyag és műgumi gyárakat és a Fresh Corner lánc bővítését. Továbbá kiemeli, hogy az elektromos autók is visszaszoríthatják a hagyományos üzemanyagok értékesítését. Ezért e stratégiaalkotó elemek és az elektromos autók külön-külön, illetve együttesen kifejtett hatásait vizsgálom a 2017-es jelenértéken számított tulajdonosi értékre nézve.
\end{abstract}

\section{LEGFONTOSABB EREDMÉNYEK}

Elemzésem alapján a fosszilis nyersanyagok felhasználásában várható esetleges váltás nem fogja befolyásolni a MOL 2030-as stratégiájának megvalósulását, a stratégiában felvázolt beruházási projektek együttesen 2,93\%-os növelő hatást gyakorolnak a vállalat tulajdonosi értékére. Ugyanakkor a MOL várakozásaival ellentétben az egyes projektek külön-külön nem mind térülnek meg 2030-ig, ez csak együttesen, a komplett stratégia vonatkozásában jelenthető ki.

\section{ÚJDONSÁGOK, GYAKORLATI JAVASLATOK}

Vizsgálati módszerem iparágon belül általánosítható, hiszen a fejlett gazdaságokban az olajipari vállalatok ugyanezekkel a trendekkel szembesülnek, kizárólag a cégspecifikus paramétereket kell megfelelően illeszteni. A MOL esetében a 2030-ig meg nem térülő projektek esetében javasolt egy hosszabb időintervallum meghatározása.

Kulcsszavak: vállalatértékelés, energiaipar, stratégiaelemzés, tulajdonosi érték, ECF modell

DOI: 10.15170/MM.2020.54.04.01 


\section{BEVEZETÉS INTRODUCTION}

Manapság már nem kérdéses, hogy a klímaváltozás és a globális felmelegedés valós tartalommal rendelkező fogalmak, amikre igenis oda kell figyelnünk. A negatív hatások csökkentése érdekében az ENSZ Éghajlat Változási Kormányközi Testülete (IPCC 2018), az EU (Európai Parlament 2014, Európai Bizottság 2014) és hazánk is (Nemzeti Fejlesztési Minisztérium 2012) a szén-dioxid radikális csökkentését irányozta elő. Az elektromos járművek számának növekedése is meghaladja az előrejelzéseket, illetve a kormányzatok világszerte tudatában vannak a klímaváltozás elleni küzdelem szükségességének (Berman, Fuhr 2017).

Ennek a kutatásnak célja kideríteni, hogy a 2030-as stratégia segítségével képes lesz-e a MOL a jövőben is legalább ilyen magas vállalatértéket generálni, vagy mint olaj-, gáz- és petrolkémiai ipari cég, ő rá is sötétebb napok várnak a jövőben? Kutatásom ennek értelmében a MOL 2030-as stratégiájának várható hatásait vizsgálja a vállalat tulajdonosi értékére nézve.

\section{AZ ALKALMAZOTT MODELL THE APPLIED MODEL}

\section{A megfelelö vállalatértékelési módszer kiválasztása \\ Choosing the right company valuation method}

A szakirodalom (Damodaran 2002, Koller et al. 2005, Fernandez 2002) többféle értékelési megközelítést bemutat, módszertanilag leginkább megfelelőnek a DCF alapú értékelést tekinti; ,a DCF az egyetlen, módszertanilag korrekt értékelési megközelítés" (Fernandez 2002, 13).

A jelenleg hatályos nemzetközi standardok ugyanígy háromféle alapvető megközelítést ismernek el: a hozamalapú (IVS 2017, 105, 40.1, 40.2), a vagyonalapú (IVS 2017, 105, 60.1, 60.2) és a szorzószámos (IVS 2017, 105, 20.1, 20.2) értékelési módszereket. Az Európában nagy jelentőséggel bíró német IDW a szorzószámos módszert önálló értékelési módként egyáltalán nem fogadja el, az legfeljebb a hozamalapú értékelés eredményének validálására használható (IDW 2008, 7.5.2, 144). A jövedelemalapú megközelítésnek számos típusa létezik, de mindegyik a DCF módszeren alapul, ezért az IVS is ezt preferálja (IVS 2017, 105, 50.1). Az IDW által kibocsátott standardok szintén a DCF módszert tartják leginkább megfelelönek a vállalatértékelés terén (IDW 2008, 4.1. 17, 4.2. 18).

A MOL Group esetében a tulajdonosok racionális választása a továbbműködtetés, a későbbi számítások pedig azt is alátámasztják, hogy a vállalat magas nyereségtermelö potenciálja miatt a hozamérték magasabb a vagyonértéknél. Mindez a hozamérték alkalmazása irányába mutat. Felmerülhet még a szorzószámos módszer, azonban egyrészt ezt mind a szakirodalom, mind a standardok bizonytalannak, könnyen manipulálhatónak tartják, illetve ezek a szorzószámok nem értékelésre, hanem árazásra használhatók.

Ezen szakmai érvek alapján a MOL 2030-as stratégia hatásainak elemzését a DCF módszerrel lehet a leghatékonyabban és legmegbízhatóbban elvégezni. A továbbiakban az elemzésem során ezt a módszert fogom használni.

Megállapítottam, hogy a MOL célja a továbbműködtetés, tehát a határozatlan időre létrehozott vállalat esetét veszem alapul, ahol a jövőbeli időszakok száma határozatlan, ezért pénzügymatematikai szempontból a végtelen időtáv feltételezésével, vagyis valamilyen örökjáradék formulával szükséges kiszámítanom a későbbi hozamok jelenértékét (Takács 2007, 2015).

Az egyes konkrét DCF modellek közül pedig az equity cash flow modellt választottam, hiszen a tulajdonosi értékre gyakorolt hatásokat szeretném kimutatni, és a tulajdonosi értéket az ECF modell adja közvetlenül eredményként.

\section{Az ECF modell alkalmazása Application of the ECF model}

A kutatási kérdés megválaszolásának eszköze tehát a 2030-ra elöre jelzett piaci változások tulajdonosi értékre gyakorolt hatásának számszerüsítése lehet. Tulajdonosi érték alatt a vállalatcsoport 2017 végére vonatkoztatott sajáttőke-értékét értem, amit DCF módszerrel, azon belül is az ECF modellel fogok megbecsülni. Megjegyzem, hogy a MOL 2016 végén jelentette be stratégiáját, ezért az azt követö, 2017-es évet tekintettem kiindulópontnak és ezért erre az évre számítottam a jelenértéket.

Az ECF modell a saját tőke értékét a jövőbeli tulajdonosi pénzáramlások jelenértékeként becsüli meg. Az ECF az a pénzáram, ami a vállalat tartóseszköz-beruházásai, a forgótőke pénzszükségletének kielégítése, a fennálló adósságállomány tőke- és kamattörlesztései, valamint az új adósság igénybevétele után a tulajdonosok számára hozamelvárásaik fedezetéül rendelkezésre áll (Takács 2015, Damodaran 2002, Koller et al. 2005, 128): 
Adózott eredmény

- Befektetett eszközök nettó növekménye

- Forgótőke növekménye

+ Finanszírozási kötelezettség növekménye

$=$ Equity Cash Flow

A tulajdonosok számára elérhető cash-flow-t a tulajdonosi hozamelvárással kell diszkontálni, amire a szerzők többsége a modellekben az re (required return on equity) jelölést használja. A jelenérték-számításhoz a szakirodalomban gyakran alkalmazott növekvő örökjáradék-modellt alkalmazom az alábbi formula szerint:

$$
S H V_{0}=E C F_{0} \frac{1+g}{r_{e}-g}
$$

ahol a SHV0 a nulladik időszakra vonatkozó tulajdonosi értéket jelöli, míg g a növekedés rátát, re pedig a diszkontrátaként szolgáló minimális tulajdonosi hozamelvárást (sajáttőke-költséget) fejezi ki. A növekvő örökjáradék-modell a hosszú távú jövőre éves bontásban elkészítendő tételes előrejelzést azzal feltételezéssel helyettesíti, miszerint a vállalat jelenben ismert éves cash- flow-ja meghatározatlanul hosszú időn keresztül évi g rátával növekedni fog, miközben a diszkontráta (re) időben nem változik.

\section{A 2030-ra várható piaci környezeti} változások tulajdonosi értékre gyakorolt hatásainak elemzése (módszertan) Analysis of the impact on shareholder value of expected market-environmental changes by 2030 (methodology)

A hatáselemzés célja, hogy a vizsgált tényezők minden mástól független, közvetlen hatásait sikerüljön számszerüen kifejezni (ceteris paribus elv). Ennek érdekében az alábbi egyszerüsítő feltételezéseket alkalmazom:

- A vállalat költségszerkezete időben nem változik.

- A társasági adókulcs időben nem változik.

- A vállalat tartóseszköz-állománya, forgótőkéje és adósságállománya alkalmazkodik az árbevételhez oly módon, hogy azok évről évre bekövetkező változásai egyenes arányban állnak az árbevétel változásával.

- A növekedési ráta és a tulajdonosi hozamelvárás (diszkontráta) a jövőben is a 2017 végén ismert szinten marad.
A VÁLLALATÉRTÉKET LEGINKÁBB BEFOLYÁSOLÓ TÉNYEZŐK MEGÁLLAPÍTÁSA, ELEMZÉSE

\section{IDENTIFYING AND ANALYSING THE FACTORS MOST INFLU- ENCING THE CORPORATE VALUE}

A „MOL 2030 - Enter Tomorrow” stratégiában megfogalmazott tényezőkre, mint a stratégia megvalósíthatóságát és megtérülését leginkább befolyásoló elemekre esett a választásom: vizsgálatukkal valid megállapításokat tehetek a vállalatértékre nézve. A beruházások 2017 és 2021 között fognak tervezetten megvalósulni, és megtérülésüket legkésőbb 2030-ra várják (MOL Group 2016). Elemzésem során a stratégiának a vállalat szemszögéből értelmezett pénzügyi megvalósíthatóságára koncentrálok, terjedelmi okokból nem foglalkozom más szereplőknél megjelenő további pozitív hatásokkal (a projektek társadalmi hasznosságával, melynek számszerüsítési módjáról például Ulbert és Takács (2007) munkája nyújt hasznos áttekintést).

\section{Elektromos autók}

\section{Electric cars}

A PwC 2014-es elektromos autók hazai számára vonatkozó előrejelzései alapján 2023-ra átlagosan $92000 \mathrm{db}$ elektromos személygépkocsi lehet forgalomban (PwC 2014).

A PwC kimutatásait alapul véve számításaim szerint 2030-ra nézve hazánkban 220800 db (2018ban 6000db, 2023-ra $92000 \mathrm{db}$, akkor 1 év alatt 3,066-szeresére növekszik a számuk, 12 év alatt 36,8-szeresére nő: $36,8 * 6000=220800)$ e-autó lesz az utakon (PwC 2014).

Továbbá a PwC szerint 2018-ban 3,3 millió személygépkocsi van forgalomban, 2023-ra 3,9 millió, akkor ugyanezen számítás mentén 2030-ra a várható személygépkocsik száma hazánkban 4 millió 740 ezer. Vagyis 2030-ra az e-autók aránya a személygépkocsikon belül várhatóan 4,658\% lesz, tehát ezzel arányosan fog csökkeni a fosszilis üzemanyagok tankolásának mértéke (PwC 2018). 


\section{Downstream üzletág: finomítók Downstream: refineries}

A stratégia célja, hogy a nem motorüzemanyag típusú termékek előállításának aránya 30\%-ról 50\%-ra növekedjen. Ennek érdekében 80-130 millió USD-t fektet be a MOL Group a finomítók fejlesztésébe (MOL Group 2017).

\section{Petrolkémia (müanyaggyártás és mü- gumi gyártás) \\ Petrochemistry (plastic production and artificial rubber production}

A MOL Group 2021-ig 2,4 milliárd USD-t fog befektetni a petrolkémiai üzletágba, hogy növelje propilén termelését, fejlessze olefin üzemeit, valamint 2015 végére megépült 35 milliárd forintból a mügumi alapanyagát képező butadién gyártására rendelt komplexum, majd 2018. március 19-én átadták magát a szintetikus gumigyárat. Az utóbbi két beruházás összértéke 130 milliárd forint volt (MOL Nyrt. 2015, MOL Group 2017, MOL Nyrt. 2018).

\section{Fresh Corner \\ Fresh Corner}

A MOL Group a stratégia meghirdetésekor 248 Fresh Cornerrel rendelkezett. Ez a szám 2017 végén 447-re nőtt, a végcél pedig, hogy 2018-ra 700 Fresh Cornerrel rendelkezzen. 2018. október 31-én 606 db Fresh Corner állt a cégcsoport rendelkezésére (Éves Jelentés 201, Éves Jelentés 2017, 2018 III. negyedéves eredmények).

\section{A MOL CSOPORT JELENLEGI TULAJDONOSI ÉRTÉKÉNEK BECSLÉSÉRE SZOLGÁLÓ MODELL \\ A MODEL FOR ESTIMATING MOL GROUP'S PRESENT SHAREHOLDER VALUE}

A MOL csoport jelenlegi tulajdonosi értékének meghatározását az alábbi lépéseken keresztül végzem el.

\section{Az adózott eredmény meghatározása Determination the result after taxation}

Az adózott eredmény a cég honlapján közzétett 2017. évi eredmény-kimutatásból közvetlenül leolvasható (1. táblázat). A későbbi számítások előkészítése érdekében a vállalat árbevételét is bemutatom.

1. táblázat: Adózott eredmény

Table 1. Result after taxation

\begin{tabular}{|l|l|}
\hline Eredménykimutatás-sor & $2017(\mathrm{mFt})$ \\
\hline Árbevétel & 4130319,7 \\
\hline Adózott eredmény & 316409,7 \\
\hline
\end{tabular}

Forrás: https://molgroup.info/hu/befektetoi-kapcsolatok/penzugyi-jelentesek/eves-jelentesek alapján 


\section{A pénzáramlásra ható mérlegváltozások meghatározása \\ Determination of balance sheet chan- ges affecting cash flow}

Az ECF az adózott eredményből származtatható oly módon, hogy azt korrigálom a nettó befektetett eszközök, a forgótőke és a finanszírozási kötelezettségek állományváltozásával. E korrekciók alkalmazásánál figyelembe veszem Broere (2014) és Takács et al. (2020) ajánlását. A szerzők arra hívják fel a figyelmet, hogy ezek az állományváltozások a vállalatok többségénél évről évre jelentős ingadozásokat mutatnak, ami hektikus cash-flow-idősort eredményez olyan cégeknél is, melyeknek számviteli eredménye stabil trendet követ. Mindez eltorzíthatja a befektetők által alkotott képet, ami elkerülhetö azzal, ha az egyes években megjelenő egyedi torzító hatásokat kiszüröm, illetve tompítom. Erre a gondolatra alapozva az ECF számítása során az említett mérlegváltozásoknak nem az utolsó évi (2017-es), hanem az utolsó öt évi (2013-2017) átlagos értékét használom fel. Ezek alapján (mFt-ban):

Nettó befektetett eszközök növekménye: 10154,8

Forgótőke növekménye: -5 053,0

Finanszírozási kötelezettség növekménye: $-79845,7$

\section{A jelenlegi Equity Cash Flow kiszámí- tása Calculation of current Equity Cash Flow}

Az előzőekben leírt paraméterek alapján a MOL Csoport jelenlegi éves tulajdonosi pénzárama a formulába való behelyettesítéssel egyszerűen levezethető (2. táblázat).

\section{A növekedési ráta és a diszkontráta megbecslése \\ Estimation of growth rate and discount rate}

A jelenérték-számításhoz szükséges két fő paraméter meghatározásához Aswath Damodaran nyilvános adatbázisát vettem alapul, mivel véleményem szerint az adott iparágba tartozó nagyszámú vállalat adataiból számított átlagértékek biztosabb alapot szolgáltatnak az értékeléshez, mint egy konkrét vállalat sok egyedi hatás által befolyásolt értékei. Ily módon a Damodaran-adattáblákból az európai „Oil/Gas (Integrated)” iparágra vonatkozó sajáttöke- költséget (Cost of Equity) és 5 évi átlagos növekedési rátát (,CAGR in Net Income - Last 5 years") gyüjtöttem ki. Ennek megfelelően a MOL Csoportot is magában foglaló európai olajipar jelenlegi átlagos növekedési rátája ( $\mathrm{g}$ ) évi 4,78\%, míg a tulajdonosok által támasztott minimális megtérülési követelmény $15,01 \%$, ezt használom diszkontrátaként $\left(\mathrm{r}_{\mathrm{e}}\right)$.

2. táblázat: Equity Cash Flow kiszámítása (adatok millió Ft-ban)

Table 2. Calculation of the Equity Cash Flow

\begin{tabular}{|l|l|}
\hline Adózott eredmény & 316409,7 \\
\hline - Nettó befektetett eszközök növekménye & 10154,8 \\
\hline - Forgótőke növekménye & $-5053,0$ \\
\hline + Finanszírozási kötelezettségek növekménye & $-79845,7$ \\
\hline = Equity Cash Flow & 231462,3 \\
\hline
\end{tabular}

Forrás: saját szerkesztés 


\section{A tulajdonosi érték megállapítása Determination of shareholder value}

Az összes szükséges paraméter kidolgozása után a vállalat tulajdonosi értékét a korábban ismertetett növekvő örökjáradék-formula segítségével számítom ki:

$\mathrm{SHV}_{0}=\mathrm{ECF}_{0} *(1+\mathrm{g}) /\left(\mathrm{r}_{\mathrm{e}}-\mathrm{g}\right)=231462,3 *$ $(1+0,0478) /(0,1501-0,0478)=2370735 \mathrm{mFt}$

\section{A 2030-ra várható piaci környezeti változások tulajdonosi értékre gyakorolt hatásainak elemzése Analysis of the impact on shareholder value of expected market-environmen- tal changes by 2030}

A módszertan részben említett egyszerüsítő feltételek mellett az árbevétel és az eredmény, az árbevétel és az ECF, valamint (a növekedési ráta és a diszkontráta állandóságának feltételezése miatt) az ECF és a tulajdonosi érték között is lineáris kapcsolat áll fenn. A 2017-es adatokból kiindulva így:

- egységnyi árbevétel-változás 0,0766 egységnyi eredményváltozást,

- egységnyi árbevétel-változás 0,0560 egységnyi ECF változást, ebből kifolyólag

- a cash-flow-t érintő mérlegváltozások egységnyi árbevételre vetítve 0,0560-0,0766=

- - -0,0206 egységnyi módosulást, továbbá

- egységnyi ECF változás 10,2424 egységnyi tulajdonosiérték-változást generál.

Számításaim során a fenti arányokat változatlannak tekintem, és minden hatást 2017 végére vonatkoztatott jelenértéken fejezek ki.

\section{Elektromos autók}

Electric cars

Korábban megállapítottam, hogy hazánkban 2030ra az e-autók aránya a személygépkocsikon belül várhatóan $4,658 \%$ lesz.

Mivel a MOL Csoport a 2017-es jelentésében nem tüntette fel, hogy a kiskereskedelmi értékesítéseken belül mekkora bevétele származik az üzemanyag értékesítésből, illetve az értékesített üzemanyag mennyiségét kizárólag kilotonnában adta meg, ezért a 2017-es átlagos üzemanyagárak (nav. hu) és az üzemanyagok sürüségének segítségével becsülöm meg a kiskereskedelemben 2017 folyamán értékesített üzemanyag mennyiségét literben és az abból származó árbevételt. Mindezek alapján megkapom, hogy 1 liter üzemanyag után hány forint nettó bevétele marad a MOL-nak: benzin: $355,6 / 1,27=280 \mathrm{Ft} / 1$ gázolaj: $360,9 / 1,27=284,2 \mathrm{Ft} / 1$ LPG: $213,42 / 1,27=168,0 \mathrm{Ft} / 1$

A 2017-es éves jelentésből kiolvasható, hogy a MOL Group teljes kiskereskedelmi üzemanyag értékesítése 2017-ben 5548 millió liter volt (Éves Jelentés 2017).

Ezek után szükséges a kilotonna - liter közötti átváltások elvégzése. A benzin sürüsége: $0,75 \mathrm{~kg} /$ liter, a gázolajé $0,83 \mathrm{~kg} /$ liter (www.gjt.bme.hu 2018). Az LPG sürüsége átlagosan $0,54 \mathrm{~kg} /$ liter (www.autogazklub.hu 2018). Az átváltások elvégzését követően levontam a nem márkakutakon értékesített mennyiséget, a visszamaradt mennyiség pedig a MOL összesített kiskereskedelmi értékesítése (3. táblázat):

$$
\begin{gathered}
\text { Benzin: } 1458569200 \text { liter } \\
\text { Gázolaj: } 4003991600 \text { liter } \\
\text { LPG: } 85439200 \text { liter }
\end{gathered}
$$

A ceteris paribus elv alapján 2030-ban 1560 584 millió forint lenne a MOL üzemanyag árbevétele, de a jelenlegi szinthez képest az elektromos autók aránya 2030-ban 4,48\%-kal több lesz a jelenleginél, ezért ugyanezzel az aránnyal fog csökkenni a 2030-as árbevétel, ami végső soron 40170 millió forintos csökkenést fog eredményezni a 2017-re vetített tulajdonosi értékben. 
3. táblázat: Az elektromos autók hatása a vállalatértékre

Table 3. The impact of electric cars on company value

\begin{tabular}{|c|c|c|c|c|}
\hline \multicolumn{5}{|c|}{ Elektromos autók } \\
\hline Üzemanyag & menny. (liter) & bruttó ár & nettó ár & árbevétel $(\mathrm{mFt})$ \\
\hline benzin & 1458569200 & 355,6 & 280,0 & 408399 \\
\hline gázolaj & 4003991600 & 360,9 & 284,2 & 1137827 \\
\hline \multirow[t]{2}{*}{ LPG } & 85439200 & 213,4 & 168,0 & 14358 \\
\hline & \multicolumn{4}{|r|}{1560584} \\
\hline \multirow[t]{2}{*}{$\begin{array}{l}\text { autók száma } \\
\text { Mo. most }\end{array}$} & összes & 3300000 & $\mathrm{db}$ & $\begin{array}{r}\text { hagyományos } \\
\text { most }\end{array}$ \\
\hline & elektromos & 6000 & $\mathrm{db}$ & $99,82 \%$ \\
\hline \multirow[t]{6}{*}{$\begin{array}{l}\text { autók száma } \\
\text { Mo. } 2030\end{array}$} & összes & 4740000 & $\mathrm{db}$ & $\begin{array}{r}\text { hagyományos } \\
2030\end{array}$ \\
\hline & elektromos & 220800 & $\mathrm{db}$ & $95,34 \%$ \\
\hline & \multicolumn{3}{|c|}{ e-arány változása: } & \multirow[t]{3}{*}{$4,48 \%$} \\
\hline & hatás az árbevételre: & -69985 & $\mathbf{m F t}$ & \\
\hline & hatás az ECF-re: & -3922 & mFt & \\
\hline & Hatás a SHV-ra: & -40170 & mFt & \\
\hline
\end{tabular}

Forrás: saját számítás

Megjegyzés: további számításaimban 300HUF/1USD árfolyamot alkalmazok, valamint az iparági ROE és tulajdonosi hozamelvárás adatok A. Damodaran adatbázisából származnak. 
Finomitók

Refineries

A finomítókkal kapcsolatos beruházások értéke 80-130 millió USD között várható, ami középértéken 105 millió USD, ez 31500 millió forintos beruházást jelent. 5,36\%-os iparági ROE és 15,01\%os tulajdonosi hozamelvárás mellett a beruházás értéke és a diszkontált hozamok alapján nettó jelenértékre - 22108 millió forintot kapok (4. táblázat). Ebből következik egy éves átlagos -2 211 millió forintos ECF hatás, így azt az eredményt kapom, hogy a finomítókra fordított beruházások 22644 millió forint negatív hatást, kiesést gyakorolnak a tulajdonosi értékre.

4. táblázat: A finomítókkal kapcsolatos beruházások hatása a vállalatértékre

Table 4. The impact of investments in refineries on company value

\begin{tabular}{|c|c|c|c|c|c|}
\hline \multicolumn{6}{|c|}{ Finomítók } \\
\hline Iparági ROE & $5,36 \%$ & ips & $\mathrm{Oil} / \mathrm{C}$ & & \\
\hline Tulajdonosi hozamelvárás & $15,01 \%$ & ipa & Oil/ & & \\
\hline 2020-ig & & 2021 & 2022 & $\ldots$ & 2030 \\
\hline Beruházás & -31500 & & & & \\
\hline Hozam & & 1688 & 1739 & $\ldots$ & 2203 \\
\hline Diszkont & 1 & 1,15 & 1,323 & $\ldots$ & 4,049 \\
\hline Diszkontált hozam & -31500 & 1468 & 1315 & $\ldots$ & 544 \\
\hline Összes NPV 2030-ig & -22108 & & & & \\
\hline Éves átlagos ECF hatás & -2211 & & & & \\
\hline Hatás a SHV-ra: & -22644 & & & & \\
\hline
\end{tabular}

Forrás: saját számitás 
Müanyaggyártás (poliol)

Plastic production (polyol)

A műanyaggyártásra a MOL Group a 2030-as stratégia értelmében összesen 2,4 milliárd USD-t fordít, ami 720000 millió forintos beruházást jelent. $15,7 \%$-os iparági ROE és $9,77 \%$-os tulajdonosi hozamelvárás mellett a beruházás és a diszkontált hozamok alapján nettó jelenértékre 66275 millió forintot kapok eredményül, amiből következik a 6 628 millió forintos éves átlagos ECF hatás. Így a mủanyaggyártásra fordított beruházások hatása a tulajdonosi értékre pozitív, 67882 millió forintot jelent (5. táblázat).

5. táblázat: A mủanyaggyártásra fordított beruházások hatása a vállalatértékre Table 5. The impact of investments in plastic production on company value

\begin{tabular}{|c|c|c|c|c|c|}
\hline \multicolumn{6}{|c|}{ Múanyaggyártás } \\
\hline Iparági ROE & $15,70 \%$ & iparág: & $\begin{array}{l}\text { Auto P } \\
\text { Packag }\end{array}$ & $\begin{array}{l}\text { fur } \\
\text { átla }\end{array}$ & shings; \\
\hline Tulajdonosi hozamelvárás & $9,77 \%$ & iparág: & $\begin{array}{l}\text { Auto P } \\
\text { Packag }\end{array}$ & $\begin{array}{l}\text { fur } \\
\text { átla }\end{array}$ & shings; \\
\hline 2020-ig & & 2021 & 2022 & $\ldots$ & 2030 \\
\hline Beruházás & -720000 & & & & \\
\hline Hozam & & 113040 & $\begin{array}{l}116 \\
431\end{array}$ & $\cdots$ & $\begin{array}{l}147 \\
492\end{array}$ \\
\hline Diszkont & 1 & 1,098 & 1,205 & $\ldots$ & 2,54 \\
\hline Diszkontált hozam & -720000 & 102979 & 96628 & $\ldots$ & 58067 \\
\hline Összes NPV 2030-ig & 66275 & & & & \\
\hline Éves átlagos ECF hatás & 6628 & & & & \\
\hline Hatás a SHV-ra: & 67882 & $\mathrm{mFt}$ & & & \\
\hline
\end{tabular}

Forrás: saját számitás 
Mügumi gyártás

Artificial rubber production

A szintetikus gumigyártásra a MOL Group összesen 130 milliárd forintot költött, ami magában foglalja a butadién gyár és a szintetikus gumigyár felépítését. $12,53 \%$-os iparági ROE és $12,46 \%$-os tulajdonosi hozamelvárás mellett a beruházás és a diszkontált hozamok alapján nettó jelenértékre -29 326 millió forintot kapok, amiből -2 933 millió forintos éves átlagos ECF hatás következik. Ez pedig összességében 30037 millió forint csökkenést eredményez a tulajdonosi értékben (6. táblázat).

6. táblázat: A mügumi gyártásra fordított beruházások hatása a vállalatértékre Table 6. The impact of investments in artificial rubber production on company value

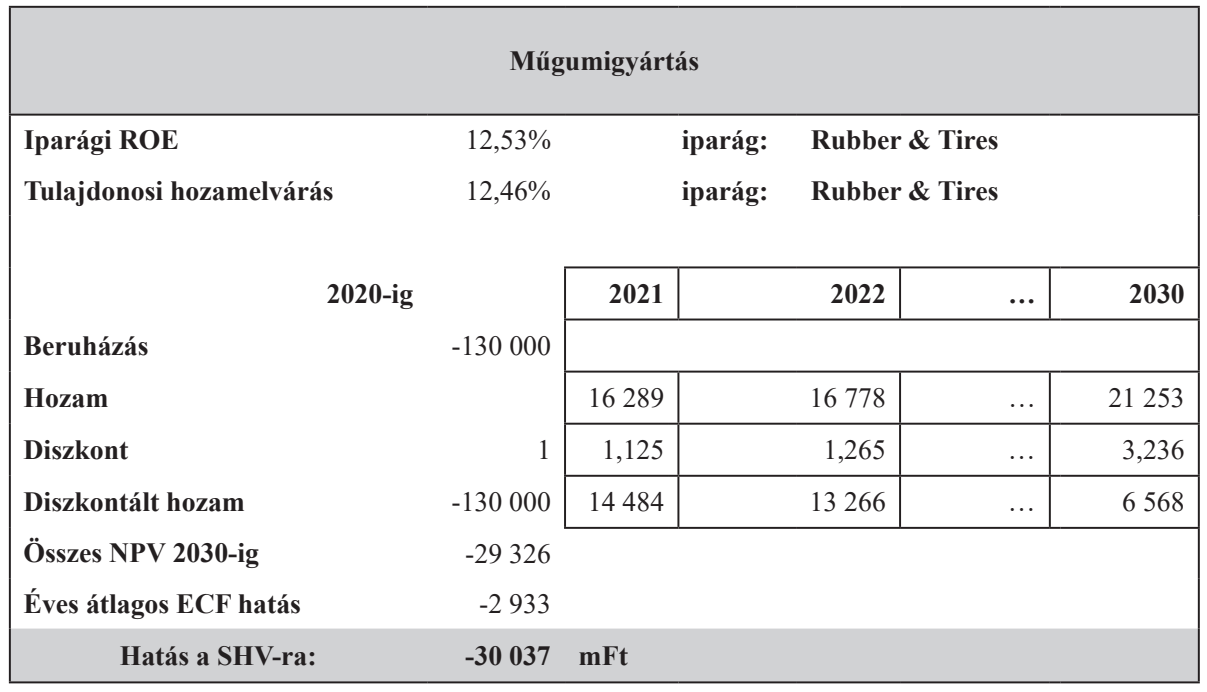

Forrás: saját számitás 
Fresh Corner

Fresh Corner

A MOL Group 2030-as stratégiájában célul tüzte ki, hogy összesen 700 Fresh Corner egységet fog üzemeltetni (7. táblázat). A 2017-es éves jelentésből kiolvasható, hogy egy Fresh Corner beruházás 197, 51 millió forintba kerül, továbbá, hogy 2017-ben
447 Fresh Corner üzemelt, így még 253 darab Fresh Corner beruházás megvalósítása a cég-csoport feladatai közé tartozik. A 253 darab beruházás együttesen 49971 millió forintot tesz ki. Számításaim során továbbá azzal a feltételezéssel élek, hogy a Fresh Corner bevétel az összes fogyasztói szolgáltatás 50\%-át teszi ki.

\section{7. táblázat: 253 darab Fresh Corner beruházási költsége}

Table 7. The investment cost of 253 Fresh Corners

$\begin{array}{llrl}\text { Fogyasztói szolgáltatások } & \text { EBITDA } & 97300 \\ & \text { Értékcsökkenés } & 25200 \\ & \text { Eredmény } & 72100 & \\ \text { ebböl Fresh Corner } & \text { FC eredmény } & 36050 & \\ & \text { Fresh Corner 2017 } & 447 & 700 \\ & \text { Fresh Corner 2020- } & 1,5660 & \\ & \text { növekmény } & 56454 & \mathrm{mFt} \\ & \text { FC Eredmény 2021- } & 20404 \mathrm{mFt} \\ & \text { Eredménynövekedés } & & \\ & & 197,51 \mathrm{mFt} \\ & \text { Egy Fresh Corner beruházás } & 253 \mathrm{db} \\ & \text { Új Fresh Cornerek 2017-2021 } & \mathbf{4 9} \mathbf{9 7 1} \mathbf{~} \mathbf{m F t} \\ & \text { Teljes beruházás } & \end{array}$

Forrás: Éves Jelentés 2017, saját szerkesztés 
Az előbb megállapított 49971 millió forintos beruházás mellett 16,89\%-os iparági ROE-val és 9,75\%-os tulajdonosi hozamelvárással számolva a beruházás és a diszkontált hozamok alapján nettó jelenértékre 92083 millió forintot kapok, amiből következik a 9208 millió forint éves átlagos ECF hatás. Ennek értelmében a Fresh Corner beruházások hatása a tulajdonosi értékre +94 316 millió forint (8. táblázat).

8. táblázat: A Fresh Corner-ekre fordított beruházások hatása a vállalatértékre Table 8. The impact of investments in Fresh Corners on company value

\begin{tabular}{|c|c|c|c|c|c|}
\hline \multicolumn{6}{|c|}{ Fresh Corner } \\
\hline Iparági ROE & $16,89 \%$ & & iparág: & Retail & \\
\hline Tulajdonosi hozamelvárás & $9,75 \%$ & & iparág: & Retail & \\
\hline 2020-ig & & 2021 & 2022 & ... & 2030 \\
\hline Beruházás & -49971 & & & & \\
\hline Hozam & & 20404 & 21016 & $\ldots$ & 26623 \\
\hline Diszkont & 1 & 1,098 & 1,205 & $\ldots$ & 2,535 \\
\hline Diszkontált hozam & -49971 & 18591 & 17448 & $\ldots$ & 10500 \\
\hline Összes NPV 2030-ig & 92083 & & & & \\
\hline Éves átlagos ECF hatás & 9208 & & & & \\
\hline Hatás a SHV-ra: & 94316 & mFt & & & \\
\hline
\end{tabular}

Forrás: saját számítás 


\section{ÖSSZEGZÉS \\ SUMMARY}

\section{A tényezök összesített hatása - The cumulative effect of the factors}

Az alábbi összefoglaló táblázat megmutatja az egyes kiemelt tényezők külön-külön mért, továbbá együttes hatását is a tulajdonosi vállalatértékre (9. táblázat).

9. táblázat: A kiemelt tényezők együttes hatása a vállalatértékre Table 9. The combined impact of the key factors on company value

\begin{tabular}{|l|r|r|r|}
\hline \multicolumn{5}{|c|}{ Összesítés } \\
\hline Tényezó & Hatás az ECF-re & Hatás az SHV-ra & 2017-es értéken, mFt-ban \\
\hline Elektromos autók & -3922 & -40170 & $-1,69 \%$ \\
\hline Finomítók & -2211 & -22644 & $-0,96 \%$ \\
\hline Mủanyaggyártás & 6628 & 67882 & $2,86 \%$ \\
\hline Mủgumigyártás & -2933 & -30037 & $-1,27 \%$ \\
\hline Fresh Corner & 9208 & 94316 & $3,98 \%$ \\
\hline Összesen & $\mathbf{6 7 7 0}$ & $\mathbf{6 9 3 4 6}$ & $\mathbf{2 , 9 3 \%}$ \\
\hline \multicolumn{5}{|r|}{} & 2370735 & \\
\hline & Bázis SHV & & \\
\hline
\end{tabular}

Forrás: saját számítás

Az eredmények alapján a legnagyobb negatív hatást az elektromos autók gyakorolják: 40170 millió forinttal, 1,69\%-kal csökkentik a vállalatértéket, ami a „,nemtankolásból” ered.

A mügumi gyártással kapcsolatos beruházás jelen körülmények között nem fog megtérülni a kívánt 2030-as időpontig, ezért célszerü lenne egy hosszabb elvárt megtérülési idő. A beruházás $2017-$ es jelenértéken kifejezve 30037 millió forint csökkenést eredményez a tulajdonosi értékben.

Ugyanez elmondható a finomítókkal kapcsolatos beruházásról, számításaim alapján ez sem fog megtérülni 2030-ra, ezért álláspontom szerint ez esetben is hosszabb elvárt megtérülési idő megadása lenne célravezető.

A műanyaggyártásnál és a Fresh Corner beruházásnál már más a helyzet: mindkettő magas megtérülést eredményez, lehetővé téve, hogy a másik három tényező hatását ellensúlyozzák.
Elemzésem alapján tehát a MOL 2030 stratégiájának pénzügyi megvalósíthatósága igazolást nyert, a stratégiában felvázolt, 2030-ig várható piaci változások kezelését célzó beruházási projektek (2017es jelenértéken kifejezve) együttesen 69346 millió forintnyi, azaz 2,93\%-os növelö hatást tesznek a vállalat tulajdonosi értékére. E hatás összegszerüségét illetve százalékos mértékét tekintve megállapítható, hogy a következő évtizedben várható változások és azok vállalatra gyakorolt hatásai nem olyan horderejüek, mint ahogy azt a napjainkban napvilágot látó hírek, piaci előrejelzések sejtetik.

\section{Érzékenységvizsgálat Test of model sensitivity}

Annak érdekében, hogy meggyőződjek modellem stabilitásáról, megbízhatóságáról, érzékenységvizsgálatot végeztem: a MOL általam számított bázis tulajdonosi értékét milyen mértékben változtatják 
meg a legfontosabb értékelési paraméterek esetleges módosulásai. Ez ugyanis hatással van a 2030-as stratégia alapján kiemelt tényezők összesített hatásának SHV- hoz viszonyított százalékos mértékére. Végkövetkeztetésem szerint 2030-ig a projektek a jelenlegi helyzethez képest mindössze $+2,93 \%$ nyi változást eredményeznek az SHV-ban, vagyis az előrevetített változások mértéke nem tekinthető jelentősnek. Az érzékenységvizsgálat során négy kulcsparamétert emeltem ki, melyek alapvetően befolyásolják a számított bázis tulajdonosi értéket:

- az árbevétel-arányos nettó eredményt (ami az általam becsülthöz képest a költségszerkezet eltérő alakulása esetén változhat meg),
- $\quad$ az ECF-re ható mérlegváltozások - a nettó befektetett eszközök, a forgótőke illetve a finanszírozási kötelezettségek állományváltozásainak - árbevételhez viszonyított százalékos hatását,

- a növekedési rátát és

- a diszkontrátaként szolgáló tulajdonosi hozamelvárást.

Arra alapozva, hogy e paramétereket megbízható adatforrások alapján, prudens módon becsültem meg, nagymértékü becslési hibát nem tartok elképzelhetőnek. Éppen ezért a fenti négy paramétert csak reális mértékben, \pm 1 százalékpontos sávban változtattam meg, majd feljegyeztem az így előálló módosult bázis SHV értékeket és a 2030-as stratégia alapján elemzett tényezők hatásának ezen módosult bázis SHV-hoz képesti százalékos arányát (10. táblázat):

10. táblázat: Érzékenységvizsgálat

Table 10. The results of the model sensitivity test

\begin{tabular}{|c|c|c|c|c|}
\hline \multicolumn{5}{|c|}{ Érzékenységvizsgálat } \\
\hline \multicolumn{3}{|c|}{$\begin{array}{l}\text { Bázis SHV: } \\
\text { Stratégia alapján kiemelt tényezők együttes hatása: }\end{array}$} & \multicolumn{2}{|r|}{2370735} \\
\hline \multicolumn{3}{|c|}{ Tényezők együttes hatása az SHV százalékában: } & \multicolumn{2}{|l|}{$2,93 \%$} \\
\hline $\begin{array}{l}\text { Értékelési } \\
\text { kulcsparaméter }\end{array}$ & $\begin{array}{c}\text { A paraméter } \\
\text { eredeti modell } \\
\text { szerinti értéke (\%) }\end{array}$ & $\begin{array}{l}\text { Alkalmazott } \\
\text { paraméterválto- } \\
\text { zás intervalluma } \\
\text { (százalékpont) }\end{array}$ & $\begin{array}{l}\text { A paraméterváltozás } \\
\text { eredményeképpen } \\
\text { elóálló bázis SHV } \\
\text { intervallum (mFt) }\end{array}$ & $\begin{array}{l}\text { A kiemelt } \\
\text { tényezök együttes } \\
\text { hatásának \%-os } \\
\text { intervalluma a } \\
\text { módosult SHV-bá- } \\
\text { zishoz képest }\end{array}$ \\
\hline $\begin{array}{l}\text { Árbevétel-ará- } \\
\text { nyos nettó } \\
\text { eredmény }\end{array}$ & 7,66 & +1 & $1947690-2793780$ & $2,48-3,56$ \\
\hline $\begin{array}{l}\text { Cash-flow-t érintő } \\
\text { mérlegváltozások } \\
\text { hatása }\end{array}$ & $-2,06$ & +1 & $1947690-2793780$ & $2,48-3,56$ \\
\hline Növekedési ráta & 4,78 & +1 & $2139017-2652663$ & $2,61-3,24$ \\
\hline $\begin{array}{l}\text { Tulajdonosi } \\
\text { hozamelvárás }\end{array}$ & 15,01 & +1 & $2159628-2627586$ & $2,64-3,21$ \\
\hline \multicolumn{3}{|c|}{ SHV bázis legtágabb intervalluma: } & $1947690-2793780$ & $2,48-3,56$ \\
\hline
\end{tabular}

Forrás: saját számitás 
A számításokból látható, hogy a kulcsparaméterek egységnyi változásai a 2030-as stratégia alapján elemzett tényezők hatásainak SHV-hoz viszonyított százalékos mértékét csak kb. plusz-mínusz fél százalékpontos sávban módosítják, ami modellem stabilitását és a levont következtetés megbízhatóságát jelzi. A korábbi számszerủ eredmény a táblázatban bemutatott érzékenységvizsgálat alapján úgy bővíthető, hogy a MOL 2030-as stratégiájában foglalt tényezők együttes hatása a 2017 -es jelenértéken számított tulajdonosi értékre 2,48\% és 3,56\% közti növelő hatást tesz, a legvalószínübb esetben e hatás az eredetileg levezetett $+2,93 \%$.

\section{Záró gondolatok, következtetések Closing thoughts, conclusion}

Előzetes várakozásom az volt, hogy az elektromos autók nagymértékben rontják majd a MOL Csoport tulajdonosi értékét; ehhez képest ez a hatás nem bizonyult jelentősnek, legalábbis 2030-ig; az elindított új projektek együttesen annak ellenére képesek ellensúlyozni az elektromos autók miatti tulajdonosiérték-csökkenést, hogy egyébként hatásuk a meglévő tulajdonosi értékre százalékosan mérve nem jelentős. Ugyanakkor fontos megjegyeznem, hogy a MOL várakozásaival ellentétben az egyes projektek külön-külön nem mind térülnek meg 2030-ig, ez csak együttesen, a komplett stratégia vonatkozásában jelenthető ki.

$\mathrm{Az}$, hogy a bevezetésben vázolt baljós jövőkép ellenére a számításaim a stratégia pénzügyi megvalósíthatóságát mutatják, egész biztosan nem jelenti azt, hogy a modellem rossz lenne. Elemzésem arra világít rá, hogy a folyamat biztosan nem olyan gyors, mint amennyire fél tőle az iparág. Az e-autók terjedése valóban negatív hatást gyakorol az olajipari cégek tulajdonosi értékére, de az alternatívaként kiépítésre kerülő tevékenységekkel, üzletágakkal a MOL Group képes lesz ezt kompenzálni.

A vizsgálati módszerem iparágon belül általánosítható, hiszen a fejlett gazdaságokban az olajipari vállalatok ugyanezekkel a trendekkel szembesülnek, kizárólag a cégspecifikus paramétereket kell megfelelően illeszteni. Mindemellett az iparágak közti általánosításra is látok lehetőséget, ugyanis hasonló kihívásokkal küzd például a dohányipar, ahol az egyre erősödő korlátozások, tilalmak miatt a hagyományos dohány iránti kereslet csökkenni fog, azonban megjelennek helyette az új technológiák; meg lehet vizsgálni, hogy ezek mennyiben képesek kompenzálni a hagyományos bevételi forrás csökkenését. A modell koncepciója tehát meggyőződésem szerint iparágon belül és iparágak között is általánosítható a cég- illetve iparágspecifikus paraméterek megfelelő kalibrálásával.

\section{HIVATKOZÁSOK REFERENCES}

Broere, M. (2014), Decision-Making in Private Equity Firms, Wiesbaden: Springer Fachmedien. DOI: 10.1007/978-3-658-03780-2

Damodaran, A. (2002), Investment valuation: Second edition, Hoboken: Wiley \& Sons

Fernandez, P. (2002), Company valuation methods. The most common errors in valuations, University of Navarra, DOI: 10.2139/ssrn.274973

IDW (2008), Grundsätze zur Durchführung von Unternehmensbewertungen, Düsseldorf: IDW

IVS (2017), International Valuation Standards, Norvich: IVS Council

Koller, T., Goedhart, M. and Wessels, D. (2005), Valuation. Measuring and managing the value of companies, Hoboken: Wiley \& Sons, DOI: $10.2307 / 2328707$

Takács A. (2007), „A számított vállalatérték és a tőzsdei részvényárfolyam kapcsolata a magyar tőzsdei vállalatoknál", Statisztikai Szemle, 85(10-11), 932-964

Takács A. (2015), Vállalatértékelés magyar számviteli környezetben, Budapest: Perfekt

Takács, A., Ulbert, J. and Fodor, A. (2020), "Have investors learned from the crisis? An analysis of post-crisis pricing errors and market corrections in US stock markets based on the reverse DCF model", Applied Economics, 52(20), 22082218, DOI: $10.1080 / 00036846.2019 .1686114$

Ulbert J., Takács A. (2007), „Energetikai beruházások társadalmi hasznosságának mérése", in: Kiss Tibor (szerk.), A biomassza energetikai felhasználásának etikai vonatkozásai: a Via futuri 2007-es konferencia válogatott, lektorált tanulmányai, Pécs, 88-99.

Internetes hivatkozások:

Autógázklub, LPG ismertető, http://www.autogazklub.hu/az-autogazrol/lpg/lpg- ismerteto/ (letöltve: 2018.11.10.)

Berman, T., Fuhr, L. Elengedhetetlen a fosszilis üzemanyagok elhagyása, https://www.vg.hu/ velemeny/elengedhetetlen-fosszilis-uzemanyagok-elhagyasa- 2-674371/ (2018.10.22.)

BME, Üzemanyag sürüségek, http://www.gjt.bme. hu/sites/default/files/kiegeszitesekatablazathoz. pdf (letöltve: 2018.11.10.)

Európai Bizottság, 2030 climate \& energy framework, https://ec.europa.eu/clima/policies/strategies/2030_en (letöltve: 2018.11.04.)

Európai Parlament, Energiapolitika: általános alapelvek, http://www.europarl.europa.eu/ 
factsheets/hu/sheet/68/energiapolitika-altalanos-elvek (letöltve: 2018.10.26.)

IPCC, Global Warming of $1.5^{\circ} \mathrm{C}$, http://www.ipcc. ch/report/sr15/ (letöltve: 2018.11.11.)

MOL Group, MOL Group Strategy 2030, https:// molgroup.info/strategy2030/

(letöltve: 2018.11.02.)

MOL Group, A MOL Csoport 2017-2021es időszakra szóló pénzügyi és működési célkitüzései, https://mol.hu/hu/molrol/mediaszoba/5938-a-mol-csoport-2017- 2021-es-idoszakra-szolo-penzugyi-es-mukodesi-celkituzesei/ (letöltve: 2018.10.28)

MOL Group, Éves Jelentés 2016, https://molgroup. info/images/molgroup/pdf/befektetoi_kapcsolatok/penzugyi_jelentesek/e ves_jelentesek/ AR_2016-book_hun_finalfinal.pdf (letöltve: 2018.05.01.)

MOL Group, Éves Jelentés 2017, https://molgroup.info/storage/documents/publikaciok/ eves_jelentesek/2017/ar_2017_book_hun.pdf (letöltve: 2018.05.01.)

MOL Group, 2018 III. negyedéves eredmények, https://molgroupcareers.info/images/molgroup/ pdf/befektetoi_kapcsolatok/penzugyi_jelentesek/negyedeves_jelentesek/Q3_sajtokozlemeny.pdf (letöltve: 2018.05.01.)
MOL Nyrt., Átadták a MOL Csoport butadién gyárát Tiszaújvárosban, https://mol.hu/hu/molrol/ mediaszoba/5648-atadtak-a-mol-csoport-butadien-gyarat- tiszaujvarosban/ (letöltve: 2018.11.12.)

MOL Nyrt., Átadták a szintetikusgumi gyárat Tiszaújvárosban, https://mol.hu/hu/molrol/ mediaszoba/6582-atadtak-a-szintetikusgumi-gyarat- tiszaujvarosban/; https://jmsr.hu/category/rolunk/hirek/ (letöltve: 2018.11.12.)

Nemzeti Fejlesztési Minisztérium, Nemzeti Energiastratégia 2030, http://2010- 2014.kormany. hu/download/4/f8/70000/Nemzeti\%20Energiastrat $\%$ C3\%A9gia $\% 202030 \% \quad$ 20teljes $\% 20$ v\%C3\%A1ltozat.pdf, 11-58. p. (letöltve: 2018.11.12.)

PwC, Merre tart az elektromos autók piaca. https:// www.pwc.com/hu/hu/kiadvanyok/assets/pdf/ merre_tart_az_elektromos_autok_piac a-ecar_2014.pdf (2018.11.03.)

$\mathrm{PwC}$, Five trends transforming the automitive industry, https://www.pwc.com/hu/hu/kiadvanyok/assets/pdf/five_trends_transforming_the automo tive_industry.pdf (letöltve: 2018.11.03.) 
Biró Zsófia, PhD hallgató

biro.zsofia@ajk.pte.hu

Pécsi Tudományegyetem

Állam- és Jogtudományi Doktori Iskola

\section{The financial viability of MOL's strategy 2030 and its effect on shareholder value}

\section{THE AIM OF THE PAPER}

In my paper, I examine the expected effects of MOL's 2030 strategy on the company's shareholder value. Will MOL Group be able to generate a suitable corporate value, if a shift in fossil era comes, or cannot deal with the upcoming future?

\section{METHODOLOGY}

I took into consideration the relevant literature and international standards. What always common is that the DCF method is the most methodologically appropriate. Within the DCF method I chose the ECF model, because the shareholder value directly derives from it.

MOL's 2030 strategy mentions four investments that are essential for shareholder value: development of refineries, plastic and artificial rubber factories and expansion of the Fresh Corner chain. It also underlines that electric cars could repress the sale of conventional fuels. I am therefore examining the effects of these strategy elements and the growing number of electric cars individually, as well as collectively on the shareholder value, at the present value 2017 .

\section{MOST IMPORTANT RESULTS}

According to my analysis, the possible shift in the use of fossil fuels will not affect the implementation of the strategy, the effects of investment projects and the fact of spreading e-vehicles, together have an increasing impact of $2.93 \%$ on shareholder value. However, contrary to MOL's expectations, individual projects will not all be reimbursed by 2030 , reimbursement can only be stated with an attention to the whole strategy.

\section{RECOMMENDATIONS}

My testing method can be generalised within the industry, since in developed economies oil companies face the same trends, only company-specific parameters need to be correctly inserted. For projects that are not reimbursed at MOL until 2030, it is recommended to define a longer time frame.

Keywords: company valuation, energy industry, strategy analysis, shareholder value, ECF model 